\section{B A Institute of \\ YK Business Administration \\ 六下 \\ Karachi \\ Leadership and Ideas for Tomorrow}

Business Review

Volume 9 Issue 1 January-June 2014

$1-1-2014$

\title{
The impact of national and organizational cultural differences on international joint venture performance
}

Rizwan Tahir

Saunders College of Business, RIT University, Dubai

Follow this and additional works at: https://ir.iba.edu.pk/businessreview

Part of the Business Commons, and the Social and Cultural Anthropology Commons

\section{c) (7)}

This work is licensed under a Creative Commons Attribution 4.0 International License.

\section{Recommended Citation}

Tahir, R. (2014). The impact of national and organizational cultural differences on international joint venture performance. Business Review, 9(1), 47-63. Retrieved from https://doi.org/10.54784/ 1990-6587.1227

This article is brought to you by iRepository for open access under the Creative Commons Attribution 4.0 License and is available at https://ir.iba.edu.pk/businessreview/vol9/iss1/4. For more information, please contact irepository@iba.edu.pk. 


\title{
ARTICLE
}

\section{THE IMPACT OF NATIONAL AND ORGANIZATIONAL CULTURAL DIFFERENCES ON INTERNATIONAL JOINT VENTURE PERFORMANCE}

\author{
Rizwan Tahir \\ Saunders College of Business \\ RIT University Dubai
}

\begin{abstract}
The purpose of this study is to theoretically explore how national cultural differences, organizational cultural differences and trust between partners can influence IJV performance. Findings from previous studies have been mixed, and this study attempts to address the relationship and performance issues by theoretically advancing a model to explain the inconclusive results found to date. Based on previous research, the findings of this study are as follows. Firstly, in terms of the relationship between national cultural differences and IJV performance, differences in the national cultures of IJV partners adversely influence IJV performance. Secondly, in the case of the relationship between organizational culture and IJV performance, differences in organizational culture between IJV partners create organizational problems that adversely influence IJV performance. Thirdly, with regard to national versus organizational cultural differences and IJV performance, organizational cultural differences represent the visible differences between, as opposed to the latent effects of, cultural differences, and these may cause greater interaction problems between the IJV partners. Fourthly, in terms of partnership trust and IJV performance, partnership trust positively influences partner interaction and venture performance. Finally, in the case of national culture, partnership trust and IJV performance, it is argued that national and organizational cultural differences adversely influence process- based trust producing mechanisms, or partnership trust. It is also empirically established that partnership trust significantly influences IJV performance. Therefore, partnership trust mediates the relationship between cultural differences and IJV performance through a chain of interactive processes.
\end{abstract}

\section{Introduction}

Growth in global markets and technologies has resulted in a dramatic increase in the number of International Joint Ventures (IJVs) (Alter \& Hage 1993; Geringer \& Woodcock 1989; Harrigan 1988; Hergert \& Morris 1988; Pothukuchi 1999), even though JVs are considered to be risky due to high failure rates (Blodgett 1992; Geringer \& Hubert 1989; Harrigan 1985; Parkhe 1993c; Porter \& Fuller 1986). An estimated $37 \%$ to $70 \%$ of IJVs are reported to suffer performances issues leading to very costly failures (Deloitte, Haskins \& Sells International 1989; Fedor \& Werther 1995; Harrigan 1985; Janger 1980). Fedor and Werther (1995:36) conclude that "an analysis of the partner's culture before structuring the cooperative venture appears to be extremely uncommon, even though this failure may lead to costly and disruptive upheavals”. A common theme in the cross-cultural literature is that ventures between culturally similar partners are more likely to be successful than ventures 
between culturally dissimilar partners, and that partners should, therefore, try to avoid cultural dissimilarities (Fedor \& Werther 1995; Harrigan 1985; 1988; Killing 1983; Lane \& Beamish 1990; Pothukuchi 1999). Some studie found a positive relationship between national cultural differences and IJV performance (see Park \& Ungson 1997), others found a negative relationship (e.g., Killing 1983; Harrigan 1985; Lane \& Beamish 1990; Geringer \& Herbert 1991), and still others found no relationship at all (e.g. Benito \& Gripsrud 1992; Sharma \& Johanson 1987; Terpstra \& Yu 1988). In all, empirical findings have been mixed and inconclusive in terms of cultural differences and their role in IJV performance. These contradictory findings increase the need for further theoretical and empirical research, and this study attempts to clarify our understanding of these complex relationships. The purpose of this study is to theoretically examine how national cultural differences, organization cultural differences and trust between partners can influence IJV performance. More precisely, it attempts to develop a theoretical framework and empirical support for two aspects of IJVs performance: first, the influence of national and organizational culture differences on joint venture performance, and second, the influence of national and organizational cultural differences on partnership trust and, consequently, IJV performance. A focus on partnership trust suggests a process-oriented theoretical approach to this study. It has been argued (Lane \& Beamish 1990; Pothukuchi 1999) that understanding the behavioural processes affecting inter-organizational relationships is central to successful performance. If organizational and national cultural differences affect performance through a mediating variable, then understanding the nature of this mediating variable is critical.

This study differs from the previous research in two aspects. Firstly, of consistency in previous results may be attributed to inadequate theoretical and empirical development. Researchers have limited their focus to only selected dimensions of cultural difference and have tended to ignore other dimensions that may have significant influence. For instance, previous studies (e.g. Hennart \& Larimo 1998) focused on the influence of national cultural differences and ignored the role of organizational cultural differences. Harrigan (1988:222) notes: "comments from interviewed managers lead me to suspect that cultural homogeneity among sponsors is more important to venture success than symmetry in their national origins".

Secondly, previous studies paid little attention to the behavioral processes involved in cross-cultural interactions, even though these processes are considered to be critical to joint venture performance (Lane \& Beamish 1990; Parkhe 1991; Ring \& Van De Ven 1994; Pothukuchi 1999). For example, studies on cross-cultural joint ventures have not considered how partnership trust influences venture performance. Lane and Beamish (1990:88) note: "We believe that the behavioral and cultural differences contributing to successful or unsuccessful cooperative ventures have not yet been fully explored or understood". A study on how cultural differences affect joint venture performance is important because it has been extensively argued that cultural differences between joint venture partners elicit conflicting behaviors that may lead to joint venture failure (Alter \& Hage 1993; Geringer \& Herbert 1989; Harrigan 1985; Parkhe 1993c; Pothukuchi 1999). This study that attempts to create a theoretical construct, based on empirical data that explains how national cultural differences, organizational cultural differences and trust between partners can influence IJV performance.

The present study proceeds in the following order. In the next section the theoretical and empirical literature on joint ventures will be summarized and the influence of national cultural differences, organizational cultural differences and partnership trust on the 
performance of international joint ventures will be discussed. The summary and main conclusions of the study will be presented in section three.

\section{Theory and Hypotheses}

\section{Cultural differences and IJV performances}

Culture is defined as the transmitted patterns of values, ideas and other symbolic systems that shape behavior (Kroeber \& Kluckhohn 1952), and IJV partners may vary based on national culture and/or organizational culture. In an empirical study of 40 countries, Hofstede (1980) found that a national culture varies along four dimensions: Power distance, Uncertainty avoidance, Individualism and Masculinity. Power distance refers to inequality among people in areas such as prestige, wealth and power, and countries differ in the value they attach to status in these areas. Uncertainty avoidance refers to the tolerance for uncertainty and ambiguity, and individualism, refers to the degree of focus on the individual, as opposed to the collective or group, prevailing in a given country.

\section{Figure 1: The framework for the present study}

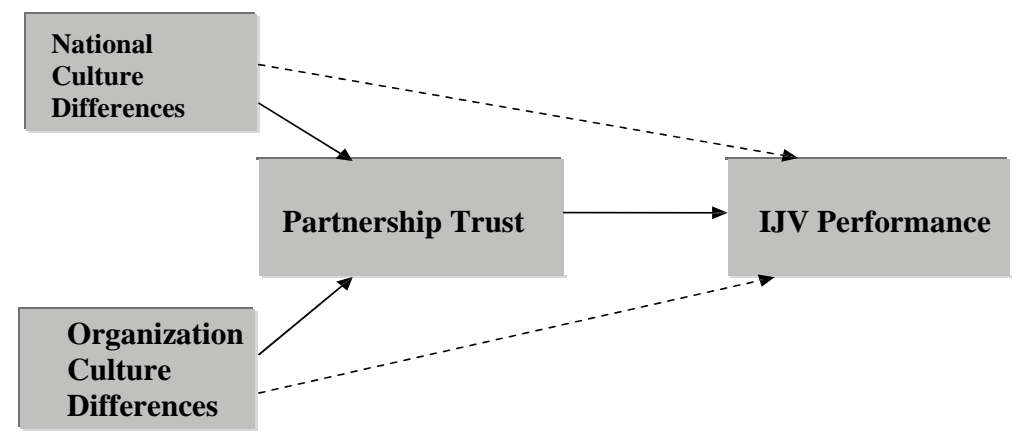

Masculinity represents the extent to which people in a country endorse goals typically ascribed to men such as competitiveness and assertiveness. Subsequent to Hofstede's original study, work with Michael Bond resulted in the addition of a fifth dimension: Confucian Dynamism (Adler, 2002). This is the degree to which a culture focuses on traditional values and is prepared to put off meeting immediate needs to access other benefits at a later stage. It is sometimes described as long and short-term focus.

In Hofstede's model, national culture has been modeled on the five values described above. In further studies, organizational culture has been modeled on six organizational practices (Hofstede, Neuijen, Daval \& Sanders 1990). In a study that spanned 10 organizations (20 organizational units) located in two countries (Denmark and Netherlands), the researchers surveyed cultural factors such as symbols, heroes, rituals and values. They concluded that organizational culture is represented by six core management practices that differentiate organizations in their management orientation. These orientations are: (1) Process versus Result Orientation; (2) Employees versus Job Orientation; (3) Parochial versus Professional Orientation; (4) Open versus Closed System Orientation; (5) Loose versus Tight Control Orientation; and (6) Normative versus Pragmatic Orientation. The first dimension process versus result orientation differentiates organizations based on their concern with means (process-oriented), versus concern with goals (result-oriented). The second dimension 
employee versus job orientation differentiates organizations on the basis of their concern for people (employee-oriented) versus a concern for getting the job done (job-oriented). The third dimension parochial versus professional differentiates organizations on the basis of employees who derive their identity largely from the organization (parochial) as opposed to from their type of job (professional). Based on system theory, the fourth dimension, open versus closed system orientation, differentiates organizations on the basis of the level of interaction within, and external to, the organization. Often, this dimension has been associated with measuring the communication climate within the organization (Poole 1985). The fifth dimension, loose versus tight control, refers to the amount of internal structuring in the organization, and finally, the sixth dimension normative versus pragmatic differentiates organizations based on their customer orientation.

\section{National Cultural Differences and IJV Performance}

Researchers have argued that differences in partners' national culture are problematic because they can cause interaction problems that ultimately adversely influence performance (Adler 1986; 1989; Goldenberg 1988; Harrigan 1988; Parkhe 1991; Tallman \& Shenkar 1994). Cross-national joint ventures have been reported to suffer from communication, cooperation, commitment and conflict resolution problems caused by partners' behavioral differences.

Communication between cross- national partners is often cited as problematic (Adler 1986; Anderson \& Weitz 1989; Camerer 1988; Sawyer 1965; Pothukuchi 1999). National cultural differences are seen to cause communication problems based on misperceptions, misinterpretation and misevaluation caused by underlying differences in values and practices (Adler 1997). In culturally diverse settings communication problems are exacerbated since perceptions, interpretations and evaluations differ, and the meaning of what is communicated is beyond words (Adler 1986; 1997). Values and thinking patterns associate underlying meaning to the words, in addition to non-verbal communication, and these underlying differences can lead to miscommunication.

Cooperative behavior (the propensity to cooperate) is seen by some researchers to vary based on differences in national cultures and ethnic grouping (Adler \& Graham 1989; Chen, Chen \& Meindl 1998; Cox 1993; Pothukuchi 1999). DeVos (1980) offers a theoretical explanation for the differing propensities to compete and cooperate. DeVos further argues that Anglo Americans tend to have a cognitive style that is "field-independent," a style that encourages autonomous decision- making and individual competition in social interaction (linking closely with Hofstede's individualism dimension). By contrast, Mexican Americans and Black Americans tend to think and respond in a "field-dependent" manner, leading them to employ more interdependent and cooperative styles (linking more closely to Hofstede's collectivism dimension). Likewise in the context of IJVs, it has been argued (Parkhe 1993d) that diversity along each cultural characteristic can be instrumental in erecting significant barriers to effective cooperation.

Commitment-generating mechanisms are different among different cultures, and the differences make it difficult to generate commitment in joint ventures (Agarwal 1993). Cullen, Johnson and Sakano (1995), for example, found that though both U.S and Japanese partners related their level of commitment to perceived benefits (satisfaction and economic performance), the partners differed in their perception of satisfaction. The Japanese partners perceived long-term organizational performance as a measure of satisfaction and emphasized 
the nature of relationship as an important factor for commitment, while their western counterparts are concerned with immediate results (linking with Hofstede's Confucian Dynamism dimension). Therefore, as with cooperation, when commitment generating mechanisms differ from country to country, commitment between cross-national partners is affected by their national cultural differences.

Finally, conflict resolution is found to be problematic because conflict resolution methods vary across cultures (Henderson 1975; Sakano \& Onzo 1990; Shenkar \& Zeira 1992). For example, US managers prefer to use direct and confrontive legal tactics in dealing with other firms when other methods fail, whereas Japanese managers prefer flexibility in responding to unfolding problems and avoid using formal detailed contracts that stress strict performance and enforcement (Henderson1975). Similarly Johnson, Sakano \& Onzo (1990) studied the role of cultural differences in conflict resolution between U.S and Japanese firms, and found that aggressive influence, as practiced in western channels, is not effective with the Japanese counterparts. Based on previous studies, it can be argued that differences in national cultures of partners caused communication, cooperation, commitment and conflict resolution problems and these interaction problems are found to adversely influence joint venture performance. Hence,

\section{H1 National cultural differences negatively influence international joint venture performance.}

\section{Organizational Cultural Differences and IJV Performance}

The organizational culture dimensions outlined by Hofstede and colleagues (1990) identify practices followed in organizations, and these are typified by a set of desirable and expected behaviors. Accordingly, typical practices and behaviors exhibited by partners reflect behaviors considered appropriate for the functioning of their respective organizations. When partners in a joint venture differ in their practices, these differences result in conflicting behaviors, leading to misunderstanding and interaction problems. The following discussion highlights how each dimension of organizational culture is grounded in a management principle upon which partnership differences may lead to interaction problems.

\section{Process versus Result Orientation Dimension}

Hofstede et al. (1990) stated that process-oriented organizations are concerned about the means by which organizations achieve a goal as opposed to the achievement of the goal itself. On the other hand, task-oriented organizations, according to Harrison (1972), consider the achievement of the super-ordinate goal as the ultimate objective of the organizational members. Altman and Baruch (1998) added that task oriented organizations allows members flexibility in communication and choosing allies. Monge and Eisenberg (1987) concluded that process-oriented and task-oriented organizations differ in their communication networks. Joint ventures typically face a complex environment, and a more decentralized (as opposed to centralized) communication network, therefore is likely to achieve both high performance and, potentially, high morale (Baskin \& Aronoff 1980). However, when partners differ in the nature of their communication networks, poor communication networks can develop along with ineffective communication and, ultimately, a lack of commitment (Jablin 1987a). Thus, differences along this dimension lead to communication and commitment problems between partners and these can adversely influence IJV performance. 


\section{Employees versus Job Orientation Dimension}

This dimension examined the attitudes an organization holds towards the employees. Hofstede et al. (1990) compared this dimension to that of Blake and Mouton's (1964) managerial grid. Blake and Mouton (1964) proposed that in job-oriented organizations leaders are more focused on the task at hand, whereas in employee-oriented organizations, leaders are more concerned about their subordinates or employees. The employee-oriented organization's reason for existence is fulfillment of employee's needs where helpfulness and caring are vehicles for managing the employees in the organization. The emphasis is on cohesiveness, participation and teamwork, where interpersonal relationships hold the organization together. The role of manager in such organization is that of a facilitator and a mentor. In the context of joint venture, it has been argued (Jablin 1987a; 1987b) that the differences in opposing styles of superior-subordinate interaction result into conflicting communication methods and, ultimately, organizational commitment problems.

\section{Parochial versus Professional Orientation Dimension}

This dimension refers to the identity of the employee. Parochial cultures comprise employees who derive their identity from the organization, whereas employees from professional cultures derive their identity from their jobs (Hofstede et al. 1990). Hofstede et al. (1990) also note that these two characteristics have been well known in the field of sociology, where they have been referred to as local versus cosmopolitan, contrasting their frame of reference (internal or external). Poupart and Hobbs' (1989) participative culture is similar to that of parochial culture, and employees in the participative culture derive their identification from the mission of the organization. Poupart and Hobbs (1989) also suggested that certain organizations are professionally oriented. The identification of employees in such organizations is related to their profession rather than the organization.

\section{Open versus Closed Systems Orientation Dimension}

This dimension of organizational culture refers to the perception of employees about the communication climate in their organizations. Open systems refer to a healthy communication climate between organization members whereas a closed system refers to a secretive and closed communication climate in the organization. Poupart and Hobbs (1989) stated that bureaucratic organizations tend to be closed due to formalization of the information. Information flow in bureaucracies seems to be vertical and distorted (Poupart \& Hobbs 1989) as opposed to information flow in participative or entrepreneurial organizations. When communication is strained due to incongruent practices between partners, mismatching expectations lead to strikingly conflicting behavior, resulting into commitment problems (Jablin 1987b).

\section{Loose versus Tight Control Orientation Dimension}

The fifth dimension mentioned by Hofstede et al. (1990) referred to the internal structuring of the organization. Tightly controlled organizations tend to be strict with respect to employee dress code, punctuality and cost-consciousness. O' Reilly et al's (1990) dimension of attention to detail is similar to that of Hofstede et al's (1990) tightly control organizations. O’ Reilly et al. (1990) suggested that detail oriented organizations tend to be precise in their operations and analytical. In the context of a joint venture, if the partners perceived each other to be practicing differing levels of control, it may be a reflection of inadequate or unresponsive communication between the partners. Differences along this 
dimension represent a mismatch in the level of organizational control and corresponding differences in the communication practices.

\section{Normative Versus Pragmatic Orientation Dimension}

It categorizes organizations into rule oriented (normative) versus customer orientated (pragmatic) based on Peters and Waterman (1982)'s maxim: staying close to the customer. The obsession with customer orientation often results in different, differentiating practices between organizations within the same industry. In the context of a joint venture, when partners differing on this dimension team up, they differ in terms of acceptable practices, in the execution of these practices and in expectations of performance. The resulting differences will be all encompassing, influencing member behavior in all aspects of the business (Peters \& Waterman 1982).

To sum up, differences in partners' organizational cultures represent opposing management practices that result in conflicting expectations and behaviors. Interaction problems are both the drivers and results of communication and commitment problems. When partners conflict in any one area, this may lead to problems in other areas of communication, cooperation, commitment and conflict resolutions management (Anderson \& Narus 1990; Baskin \& Aronoff 1980; Jablin 1987a; 1987b; Pothukuchi 1999). In other words, differences in organizational practices result into interaction problems between partners, and these, in turn, adversely influence joint venture performance. Hence,

H2 Organizational cultural differences between partners negatively influence international joint venture performance.

\section{National versus organizational cultural differences and IJV performance}

Several earlier studies (e.g. Fey, Beamish \& Makino 1995) have found conflicting or non-significant findings in terms of how national cultural affects merger and acquisition performance. However, traditional IJV scholars (e.g. Schuller, Dowling \& Cieri 1992; Brown 1990) have suggested that national and cultural similarity positively affect IJV performance. Their reasoning is that they perceive national cultural homogeneity to be less important as a determinant of IJV performance than is organizational cultural similarity (Fey 1997). Similarly Brown, Rugman and Verbeke (1989:237) hypothesize that in IJVs "the compatibility of organizational cultures is more important than similarity of national origin." However, the relative influence of national versus organizational culture differences on joint venture performance has not been examined extensively in the literature (Hofstede et al. 1990). Considering that these two constructs possess different characteristics, it is of theoretical and practical significance to explore which of these two have more influence on the performance of IJV.

As noted above, whereas national cultural differences represent values that are latent, subtle and, as such, are not observable, organizational culture differences are reported to represent the visible and striking aspect of common practices: symbols, heroes and rituals that represent a discrete number of independent dimensions are well rooted in organizational theory (Hofstede et al., 1990). There are, therefore, basically two reasons to believe that the organizational culture differences are more directly related to IJV performance than the national cultural differences. Firstly, organizational cultures represent management practices that are directly relevant to IJV performance, as opposed to national cultures that are rooted in societal values and are, therefore, related in a more indirect way. In other words, 
the influence of organizational culture is more context- specific to joint venture performance than national culture. Secondly, from a social learning theory (SLT) perspective (Bandura 1977), it has been argued that when partners begin to interact, they observe only the visible and striking behavior differences as opposed to unobservable latent differences (Black \& Mendenhall 1991). Therefore, by definition, since organizational cultural differences represent the visible differences, they cause greater interaction problems, thus leading to adverse influence on IJV performance. Similarly Black and Mendenhall (1991) argued that partners encountering a new culture tend to pay attention only to those elements of the new culture that are similar to their home culture, or they super impose familiarity on anything that even resembles familiar clues.

This selective cognition results in a honeymoon period during which cross- cultural joint ventures survive in spite of cultural differences. There are three reasons for such a behavior. First, a lack of familiarity with new cultures and an inability to recognize negative cues as instances of negative feedback. Second, a propensity to protect prior selfconcepts and ignore recognizable negative feedback in order to maintain the prior selfconcept. Third, relatively little time during the initial encounter may limit the partners' ability and compulsion to recognize negative consequences. Consequently, these factors lead partners to perceive each other's cultures selectively and observe only those factors that are either common to both or are strikingly different (Black \& Mendenhall 1991).

Fichman and Levinthal (1991) also provide a complementary theoretical explanation for understanding the honeymoon period. Partners start a joint venture with an initial stock of assets in form of favorable prior beliefs, trust, goodwill, etc., and these reduce the risk of the venture dissolving even if the initial outcomes of the relationship are unfavorable. To sum up, these theories suggest that partners are selective in their perceptions and have good will in the initial stages of the interaction. Therefore, during this phase, they observe only behaviors that fit positively into pre-existing paradigms, or they notice visible and strikingly conflicting behavior, which, in reality, may or may not culminate in interaction problems later. Importantly though, it is the organizational culture differences that are noticed in terms of positive and/or visibly conflicting behaviors. The less obvious and latent effects of national culture differences are not noted in these early stages. Therefore,

\section{H3 Organizational cultural differences affect international joint venture performance} more significantly than national culture differences.

\section{Cultural Differences, Partnership Trust and IJV Performances}

"Trust is a psychological state comprising the intention to accept vulnerability based upon positive expectations of the intentions or behavior of another." "Partnership trust", as opposed to "trust" is more relevant in the joint venture context, and is not yet sufficiently understood, but it continues to draw scholarly attention (Rousseau, Sitkin, Burt \& Camerer 1988). Since partnership trust appears to be essential for long-term success, and cultural differences are argued to influence partnership trust, it is necessary to examine the role of culture in terms of building and maintaining trust, and to identify the role of partnership trust on IJV performance.

\section{Partnership Trust and IJV Performance}

Trust is a very important concept in IJVs, and the establishment of trust is seen as fundamental to effective cooperation and successful partnership building. Further, trust 
reduces, or manages complex and uncertain realities far more quickly and economically than prediction, authority or bargaining. Many definitions of trust exist in the literature. One of the most useful is Gambetta's (1988:217): “Trust is a particular level of the subjective probability with which an agent assesses that another agent or group of agents will perform a particular action both before he can monitor such action and in a context in which it affects his own action. When we say we trust someone or that someone is trustworthy, we implicitly mean that the probability that he will perform an action that is beneficial or at least not detrimental to us is high enough for us to consider engaging in some form of cooperation with him.” Trust has been acknowledged in transaction cost theory to be the most efficient mechanism for overseeing transactions (Ouchi 1980, Fey 1997). Trust can act like the glue that holds together and stabilizes a relationship, and it accomplishes this stabilization by inducing reciprocity and coordinating action (Fey 1997; Ouchi 1980; Blau 1964). Trust begins to develop when one partner exercises forbearance, and this, in turn, creates the opportunity to develop some reverse goodwill through reciprocity that, it leads to more trust building (Frey 1997). Additionally, the stock of goodwill can be used at a later time when the need arises. Thus, trust can be said to facilitate tolerance of unavoidable short-term inequities that, in the absence of trust, could be a source of potential conflict. Trust fosters this tolerance by creating a long-term orientation in which partners might expect reciprocal behavior and greater benefits. Having trust in the partner allows for a looser formal contractual relationship since trustcan partially replace such a contract. It has been argued that trust is advantageous because it strengthens inter organizational ties (Fichman \& Levinthal 1991), speed contract negotiations (Reve 1990), reduces transaction costs (Bromiley \& Cummings 1993; Parkhe 1993d) and breeds repeated ties (Gulati 1995). Studies have found that partnership trust positively influences communication, cooperation, commitment and conflict resolution between partners, thus improving partner interaction and venture performance (Anderson, Lodish \& Weitz 1987; Anderson \& Narus 1990; Anderson \& Weitz 1989; Parkhe1993d; Roberts \& O’ Reilly 1974).

IJV scholars (Hebert 1994; Parkhe 1993) have asserted that trust reduces the incentives for opportunistic behavior, and thus reduces transaction costs in IJVs by inducing the partner to take a longer-term view. These actions results in the long-term viability and efficiency of IJVs (Beamish \& Banks 1987).

Previous empirical studies have found a statistically significant direct relationship between partnership trust and IJV performance, and have found partnership trust to be a fundamental factor in the formation, stability and survival of IJV (Inkpen, Currall \& Hughes 1995; McAllister 1995; Mohr \& Spekman 1994). Mohr and Spekman (1994) found that partnership trust positively influences IJV performance. Further, Zaheer and Venkatraman (1995) found partnership trust to be a required characteristic for the functioning of a partnership, and Ink pen, Currall and Hughes (1993) found that partnership trust influences venture performances through forbearance as a mediating variable. Building on the above discussions and past theoretical work (e.g. Gulati 1995; Madhok 1995; Parkhe 1993; Beamish 1984) and empirical work (e.g. Hebert 1994; Inkpen 1992; and Subieta 1991), it is asserted that trust is of central importance for IJVs to perform well. Thus,

H4: $\quad$ Partnership trust positively influences international joint venture performance. 
National and Organizational Cultural Differences, Partnership Trust and IJV Performance

If partnership trust is central to the functioning of joint ventures, it is of interest to identify how cultural differences influence partnership trust. More specifically, it is of interest to focus on partnership trust (as opposed to multiple layers of trust) and how it is developed.

In an inter-organizational context, Zucker (1986) identified several mechanisms that result in inter- organizational trust and classified them into three modes. First characteristicsbased trust may develop based on similarity of characteristics such as family background, ethnicity, sex or nationality. In cases like this, background understandings are presumed to be held in common, smoothing out or eliminating negotiation over terms of exchange and making it more likely that the outcome of the exchange is satisfactory (Zucker 1986). In the context of IJVs, similarity of nationality serves as this index. Empirical studies that focused on international strategies of firms found that similarity of nationality has been a positive factor in terms of future investment and expansion (Davidson 1980; Kogut \& Singh 1988; Shane1994). Characteristics-based trust then is closely linked to national culture.

Second, process-based trust is developed based on the interaction between the partners whereby communication, cooperation, commitment and conflict resolution problems associated with cross-cultural interaction play a significant role (Pothukuchi 1999). In the business world, mechanisms such as reputation (a symbolic representation of past exchange history) and brand name (a deliberately constructed proxy for reputation), are proposed as indicators of process based trust (Zucker 1986). Gulati (1995) found that repeated alliances between the same partners breeds interfirm trust based on mutual experiences. Process-based trust then appears to be more closely linked to organizational culture. Finally, institutional-based trust is embedded in formal mechanisms rather than in overt cultural characteristics, or in the past history of exchange. Zucker (1986) notes that institutional-based trust can be person or firm specific (e.g., medical doctors), or based on intermediary mechanisms (bank supervision of escrow accounts).

In the context of IJVs, Parkhe (1993d) identified mechanisms such as certification, credentialing or professional associations (such as New York Stock Exchange) as examples of firm specific institutional mechanisms. Parkhe (1993d) also identified holding, mutual hostages, reciprocal agreements, contractual provisions in formal partnership agreements and inflicting penalties for omission of cooperative behaviors as examples of intermediary mechanisms. Both national and organizational cultural differences, then, have an adverse influence on partnership trust. As discussed earlier, national and organizational culture differences cause interaction problems between partners in the form of communication, cooperation, commitment and conflict resolution. It has been argued (e.g. Anderson, Lodish \& Weitz 1987; Anderson \& Narus 1990; Anderson \& Weitz 1989) that communication is an important instrument in influencing trust between partners. In an empirical study of 690 relationships involving manufactures and their sales agents, Anderson and Weitz (1989) found very strong relationship between trust and communication wherein both the variables positively influenced each other. In another empirical study of manufacturing and distribution firms, Anderson and Narus (1990) found strong empirical support for the relationship between communication and trust. They found that communication affects cooperation in the partnership, and that, in turn affects trust.

Similarly, researchers concluded (Anderson \& Narus 1990; Axelrod 1984; Parkhe 
1993d; Ring \& Van de Ven 1994) that cooperation between partners influences trust between partners. A growing and successful history of cooperation results in an increased potential for the future relationship, and creates apositive reputation for both firms as trustworthy partners (Axelrod 1984). From the perspective of symbolic interactionism, trust, interpersonal cooperation and teamwork intertwine in ways that mutually influence each other (Jones \& George 1998). Anderson and Narus (1990) empirically found that cooperation affects trust in inter organizational partnerships.

Researchers (Anderson \& Weitz 1990; Parkhe 1993d; Ring \& Van de Ven 1994) propose that commitment and trust between partners are interactive and necessary for successful alliance formation and performance. There are arguments that highlight the interdependent relationship between trust and commitment. Parkhe (1993d) points out that one of the functions of trust is to generate cooperation between parties involved in the exchange. Partners create positive exit barriers that reduce fear of opportunism, while trust induces assurance about other's intentions and relationship's viability. Exante measures of commitment seek to enhance trust through a show of good faith, and lock the partners into delivering expected performance for fear of losing valuable resources (Parkhe1993d). In an argument emphasizing the reciprocal relationship, Anderson and Weitz (1990) argued that building commitment involves undertaking genuine risks on the part of both parties, and that assuming risk in turn deepens one's commitment fueling a process of signaling and reciprocation. Trust between the parties enables them to undertake these risks, and thereby facilitates commitment.

Researchers also argued that trust is at the center of preferred mode of conflict resolution (Peterson \& Shimada 1978; Sullivan, Peterson, Kameda \& Shimada 1981). If parties trust one another, then re-negotiation of the formal contract or the use of arbitration is unnecessary (Ballon 1978; Peterson \& Shimada 1978). In a study that explored the relationship between conflict resolution and trust involving Japanese-American joint ventures in Japan, Japanese managers perceived a higher level of future mutual trust when disputes are resolved through conferral, except when Americans are in-charge of operations (Sullivan, Peterson, Kameda \& Shimada 1981). This implies that the level of trust in the partners influence the choice of conflict resolution mechanism.

Interaction processes between potential partners is a dynamic two-way process that requires trust. However, adverse interaction processes negatively affect process-based trust that in turn might negatively affect partner selection. The opposite is also true wherein positive interaction reinforces partnership trust that in turn promotes appropriate (mutually amicable) behaviors (Pothukuchi 1999). This two- way relationship between communication, cooperation, commitment and conflict- resolution processes and partnership-trust highlights the importance of these interaction processes as trust producing mechanisms (process based).

As discussed earlier, national and organizational culture differences adversely influence these interaction processes. Cumulatively, these arguments imply that national and organizational cultural differences adversely influence process-based trust- producing mechanisms, and through these mechanisms, negatively affect partnership trust. It has also been argued, and empirically established, that partnership trust significantly influences IJV performance. Thus, partnership trust mediates the relationship between cultural differences and IJV performance through a chain of interaction processes. 
H5: National culture differences adversely influence international joint venture performance through partnership trust as a mediating variable

H6: Organizational culture differences adversely influence international joint venture performance through partnership trust as a mediating variable.

\section{Summary and Conclusions}

The purpose of this study was to theoretically explore how organizational cultural differences, national cultural differences and trust between partners can influence the IJV performance. In previous studies, it has been argued that cultural differences have a negative influence on the IJV performance; however, empirical findings have been confusing and contradictory. Some studies have found a positive relationship between partner's cultural differences and IJV performance, while other found a negative relationship, and yet others found no relationship between the two constructs at all. These contradictory findings continue to confuse the nature of the relationship between cultural differences and IJV performance. This study proposes a theoretical construct to examine these complex relationships. The findings of this study are as follows. First, in terms of the relationship between national cultural and IJV performance, it is found that differences in the national cultures of IJV partners may cause communication, cooperation, commitment and conflict resolution problems, and these interaction problems are found to adversely influence IJV performance. Secondly, with regard to the relationship between organizational culture and IJV performance, it can be concluded that differences in organizational culture of IJV partners' results in conflicting expectations, behaviors and interaction problems, and these adversely influence IJV performance. Thirdly, in the case of national versus organizational cultural differences and IJV performance, it is argued that organizational cultural differences represent the visible differences as opposed to the latent effects of national cultural, and they cause greater interaction problems between the IJV partners. Thus, it can be concluded that organizational cultural differences between the partners affect the IJV performance more significantly than the national culture differences. Fourthly, in the case of partnership trust and IJV performance, it is found that partnership trust positively influences communication, cooperation, and commitment and conflict resolution between partners, thus improving partner interaction and venture performance. Finally, in terms of national culture, partnership trust and IJV performance, it is argued that national and organizational cultural differences adversely influence process- based, trust-producing mechanisms and thus, partnership trust. It is also empirically established that partnership trust significantly influences IJV performance. Therefore, partnership trust mediates the relationship between cultural differences and IJV performance through a chain of interaction processes.

This study has a number of limitations. The present study primarily relies on Hofstede's (1980) and Hofstede et al. (1990) dimensions of national and organizational cultures. While these measures are used in this study as they represent the most empirically accepted and used dimension of culture, they do not represent a comprehensive list of cultural dimensions used by previous studies. For instance, low and high context communication dimensions have been theoretically proposed to influence the nature of communication and cooperation between partners (Chen, Chen \& Meindl 1998; Gudykunst 1994; Gudykunst \& Ting- Toomey 1988). There are also other measures including value orientations (Kluckhohn \& Strodtbeck 1961), pattern variables (Parsons \& Shil, 1951), 
structural tightness (Boldt, 1978) that have not been used in this study. The scope of this study, then, is limited to the representativeness of Hofstede's (1980; 1990) dimensions. Future studies can explore and test the usefulness of other culture dimensions.

\section{References}

Adler, N.J. (1986) International Dimensions of Organizational Behavior. Boston, MN: Kent

Adler, N.J. (1997). International Dimensions of Organizational Behavior. Cincinnati, OH: South-Western College Publishing.

Adler, N.J. (2002). International Dimensions of Organizational Behavior. Cincinnati, OH: South- Western Thomson Learning.

Adler, N.J. and Graham, J.L. (1989) 'Cross-Cultural Interaction: The International Comparison Fallacy’, Journal of International Business Studies 20: 515-537.

Agarwal, S. (1993) 'Influence of formalization on role stress, organizational commitment, and work alienation of salespersons: A cross-national comparative study’, Journal of International Business Studies 24(4): 715-739.

Alter, C. and Hage, J. (1993) Organizations Working Together. Sage Publishers: Newbury Park, CA. Anderson, E. and Weitz, B.A. (1989) 'Determinants of continuity in conventional industrial channel dyads', Marketing Science 8: 310- 323.

Anderson, E., Lodish, L.M. and Weitz, B.A. (1987) 'Resource allocation behavior in conventional channels', Journal of Marketing Research 24: 254-265.

Anderson, J.C. and Narus, J.A. (1990) 'A model of distribution firm and manufacturing firm working partnerships', Journal of Marketing 54: 42-58.

Axelrod, R. (1984) The evolution of cooperation. New York: Basic Books.

Ballon, R.J. (1978) 'A European views the Japanese’, The Wheel Extended, Summer : 1-5.

Bandura, A. (1977) Social learning theory. Englewood Cliffs, NJ: Prentice-Hall.

Barkema, H., Bell, J. and Pennings, J. (1996) 'Foreign entry, cultural barrier, and learning' Strategic Management Journal 17: 151-166.

Baskin, O.W. and Aronoff, C.E. (1980) Interpersonal Communication in Organizations. Santa Monica, CA: Goodyear Publishing Company, Inc.

Beamish, P.W. and Banks, J.C. (1987) 'Equity joint ventures and the theory of the multinational enterprise', Journal of International Business Studies 18: 1-16.

Beamish, P.W. (1984) Joint venture performance in developing countries. Unpublished doctoral dissertation, University of Western Ontario.

Benito, G. and Gripsurd, G. (1992) 'The expansion of foreign direct investment: Discrete rational location choices or a cultural learning process'? Journal of International Business Studies 23: 461-476.

Black, J.S. and Mendenhall, M. (1991) 'The U-Curve Adjustment Hypotheses Revisited: A Review and Theoretical Framework', Journal of International Business Studies 23(2): 225-47. 
Blake, R.R. and Mouton, J.S. (1964) The managerial grid. Houston, TX: Gulf.

Blodgett, L.L. (1992) 'Factors in the instability of international joint ventures: An event history analysis’, Strategic Management Journal, 13(6): 475-481.

Bromiley, P. and Cummings, L.L. (1993) 'Organizations with trust: Theory and measurement' Academy of Management Annual Meetings, Atlanta.

Burns, T. and Stalker, G.M. (1961) The management of innovation. London: Tavistock.

Business Week. (1986) 'Corporate odd couples: Joint ventures are the rage, but the matches often don’t work out’, Business Week, July 21: 100-105.

Business Week. (1989) 'When U.S. joint ventures with Japan go sour', Business Week, July 24: 30-31.

Chen, C.C., Chen, X. and Meindl, J.R. (1998) 'How can cooperation be fostered? The cultural effects of individualism-collectivism', Academy of Management Review 23(2): 285-304.

Cox, T.H. (1993) Cultural Diversity in Organizations. San Francisco: Berrett-Koehler Publishers.

Cullen, J., Johnson, J.L. and Sakano, T. (1995) 'Japanese and Local Partner Commitment to IJVs: Psychological Consequences of Outcomes and Investments in the IJV Relationship', Journal of International Business Studies 26(1): 91-115.

Davidson, W. (1980) 'The location of foreign direct investment activity: Country characteristics and experience effects', Journal of International Business Studies 11: 9-23.

Deloitte, Haskins and Sells International. (1989) Teaming up for the nineties-Can you survive without a partner? New York: Deloitte, Haskins and Sells.

De Vos, G.A. (1980) 'Ethnic adaptation and minority status', Journal of Cross-Cultural Psychology 11(1): 101-124.

Fedor, K.J. and Werther, J. (1995) 'Making Sense of Cultural Factors in International Alliances’, Organizational Dynamics 23(4): 33- 48.

Fichman, M. and Levinthal, D.A. (1991) 'Honeymoons and the liability of adolescence:

A new perspective on duration dependence in social and organizational relationships', Academy of Management Review 16: 442-468.

Gambetta, D. (1988) Trust: Making and breaking cooperative relations. New York: Basil Blackwell.

Geringer, J.M. and Herbert, L. (1989) 'Controland performance of international joint ventures’, Journal of International Business Studies 20(2): 235-254.

Geringer, J.M. and Herbert, L. 1991. Measuring performance of international joint ventures. Journal of International Business Studies, 22(2): 249-263.

Geringer, J.M. and Woodcock, C.P. (1989) 'Ownership and control of Canadian joint ventures’, Business Quarterly 54(1): 97-101.

Goldenberg, S. (1988) Hands across the ocean: Managing joint ventures. Boston: Harvard Business School Press. 
Gulati, R. (1995) 'Does Familiarity Breed Trust? The Implications of Repeated Ties for Contractual Choice in Alliances’, Academy of Management Journal 38(1): 85-112.

Harrigan, K.R. (1985) Strategies for Joint Venture Success. Lexington. MA: Lexington Books.

Harrigan, K.R. (1988) 'Strategic Alliances and Partner Asymmetries' in F.J. Contractor \& P. Lorange (eds.), Cooperative Strategies in International Business: 205-226. Lexington, MA: Lexington Books.

Henderson, D.F. (1975) Foreign Entries in Japan. Chapel Hill: University of North Carolina Press.

Herdert, M. and Morris, D. (1988) 'Trends in international collaborative agreements' in F. Contractor and P. Lorange (eds.), Cooperative strategies in international business: 99-109. Lexington, MA: Lexington Books.

Hofstede, G. (1967) The game of budget control. London: Tavistock.

Hofstede, G. (1980) Culture’s consequences. Beverly Hills, CA: Sage.

Hofstede, G., Neuijen, B., Ohayv, D.D. and Sanders, G. (1990) 'Measuring Organizational Cultures: A Quantitative Study across Twenty Cases’, Administrative Science Quarterly, 35: 286-316.

Inkpen, A.C., Currall, S.C. and Huges, S. (1995) 'International Joint Venture Trust: An Empirical Examination’, Academy of Management, Vancouver.

Jablin, F.M. (1987a) 'Formal organizational structure’ in F.M. Jablin, L.L. Putnam, K.H. Roberts and L.W. Porter(eds.), Handbook of organizational communication: 389- 419. Newbury Park, CA: Sage.

Jablin, F.M. (1987b) ‘Organizational entry, assimilation, and exit’ in F.M.

Jablin, L.L. Putnam, K.H. Roberts and L.W. Porter (eds.), Handbook of organizational communication: 679-740. Newbury Park, CA: Sage. Janger, A.R. (1980) Organization of international joint ventures. New York: Conference Board.

Johnson, J.L., Sakano, T. and Onzo, N. (1990) 'Behavioral Relations in Across-Culture Distribution Systems: Influence, Control and Conflict in U.S. Japanese Marketing Channels', Journal of International Business Studies 21(4): 639-655.

Jones, G.R. and George, J.M. (1998) 'The experience and evolution of trust: Implications for cooperation and teamwork’, Academy of Management Review 23(3): 531-546.

Killing, J.P. (1983) Strategies for joint venture success. New York: Praeger.

Kogut, B. and Singh, H. (1988) 'The effect of natural culture on the choice of entry mode', Journal of International Business Studies 19: 411-432.

Lane, H.W. and Beamish, P.W. (1990) 'Cross-Cultural Cooperative Behavior in Joint Ventures in LDCs’, Management International Review 30(special Issue): 87-102.

Madhock, A. (1995) 'Revisiting Multinational Firms’ Tolerence for Joint Ventures: A TrustBased Approach’, Journal Of International Business Studies 26(1): 117-137. 
Mc Allister, D.J. (1995) 'Affect- and Cognition-Based Trust as Foundations for Interpersonal Cooperation in Organizations’, Academy of Management Journal 38(1): 24-59.

Mohr, J., and Spekman, R. (1994) Characteristics of Partnership Success: Partnership Attributes, Communication Behavior, and Conflict Resolution Techniques', Strategic Management Journal 15(2): 135-152.

Monge, P.R. and Eisenberg, E.M. (1987) 'Emergent communication networks', in F.M. Jablin, L.L. Putnam, K.H. Roberts, and L.W. Porter (eds.), Handbook of organizational communication: 304-342. Newbury Park, CA: Sage.

Ouchi, W.G. (1980) 'Markets, bureaucracies, and clans' Administrative Science Quarterly 25:129-142.

Park, S.H. and Ungson, G.R. (1997) 'Re-examining national culture, organizational complementarity, and economic motivation on joint venture dissolution' Academy of Management Journal 40(2): 279-307.

Parkhe, A. (1991) 'Interfirm Diversity, Organizational Learning, and Longevity in Global Strategic Alliances', Journal of International Business Studies 22(4): 579-601.

Parkhe, A. (1993b) 'Partner nationality and the structure-performance relationship in strategic alliances’, Organization Science 4(2): 301-324.

Parkhe, A. (1993c) 'Strategic alliance structuring: A game theoretic and transaction cost examination of interfirm cooperation', Academy of International Business Meeting, Hawaii.

Peters, T.J. and Waterman, R.H. (1982) In search of excellence: Lessons from America's best run companies. New York: Harper \& Row.

Poole, M.S. (1985) 'Communication and organizational climates: Review, critique, and a new perspective', in R.D. McPhee and P.K. Tompkins (eds.), Organizational Communication: Traditional Themes and New Directions: 79-108. Beverly Hills, CA: Sage.

Porter, M.E. and Fuller, M.B. (1986) 'Coalitions and global strategies', in M.E. Porter (ed.), Competition in global industries: 315-343. Cambridge, MA: Harvard University Press.

Roberts, and L.W. Porter (eds.), Handbook of Organizational Communication: 549-599. Newbury Park, Ca: Sage.

Peterson, R.B. and Shimada, J.Y. (1978) 'Sources of management problems in Japanese-American joint ventures' Academy of Management Review 3: 796-804.

Redding, W.C. (1972) Communication within the organization: An interpretive review of theory and research. New York, NY: Industrial Communication Council.

Reve, T. (1990) 'The firm as a nexus of internal and external contracts', in M. Aoki, B. Gustafson, and O. Williamson (eds.), The firm as a nexus of treaties: 133-161. Newbury Park: Sage.

Ring, P.S. and Van de Ven, A. (1994) 'Developmental processes of cooperative inter organizational relationships', Academy of Management Review 19: 90-118.

Roberts, K.H. and O’Reilly, C.A.O. (1974)'Measuring organizational communication’, Journal of Applied Psychology 59: 321-326. 
Shane, S. (1994) 'The Effect of National Culture on the Choice between Licensing and Direct Foreign Investment', Strategic Management Journal 15: 627-642.

Sharma, D. and Johanson, J. (1987) ‘Technical consultancy in internationalization’, International Marketing Review 20-29.

Shenkar, O.and Zeira, Y. (1992) 'Role Conflict and Role Ambiguity of Chief Executive Officers in International Joint Ventures’, Journal of International Business Studies 23(1): 5575.

Sullivan, J., Peterson, R.B., Kameda, N. and Shimada, J. (1981) 'The Relationship between Conflict Resolution Approaches and Trust- A Cross Cultural Study', Academy of Management Journal 24(4): 803-815.

Tallman, S.B. and Shenkar, O. (1994) 'A managerial decision model of international cooperative venture formation’, Journal of International Business Studies 25(1): 91-113.

Terpstra, V. and Yu, C. (1988) 'Determinants of Foreign investment of U.S. advertising agencies’ Journal of International Business Studies 19: 33-46.

Zucker, L.G. (1986) 'Production of Trust', Research in Organizational Behavior 8: 53-111.

Individual executives who have developed specific skills create superior organizational performance. Excellence doesn't happen miraculously but springs from pacesetting levels of personal effectiveness and efficiency. Great business, government, and nonprofit organizations owe their greatness to a few individuals who mastered leadership skills and passed those skills on to succeeding generations of executives and managers.

Creating Excellence 